\title{
Evaluation of Microreactor Inhalation Dose Consequences
}

\author{
Troy P Reiss
}

April 2020

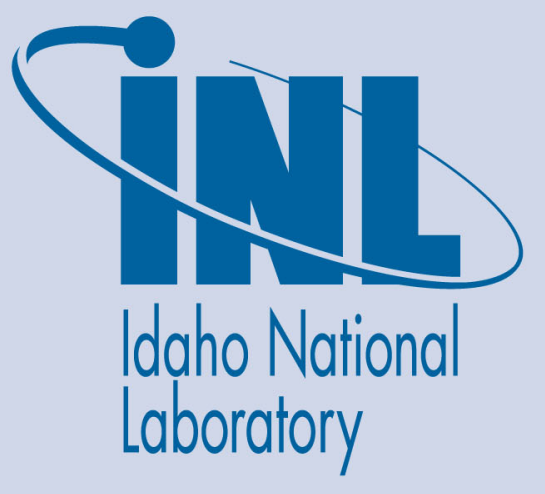

The INL is a U.S. Department of Energy National Laboratory operated by Battelle Energy Alliance 


\title{
Evaluation of Microreactor Inhalation Dose Consequences
}

\author{
Troy P Reiss
}

April 2020

Idaho National Laboratory Idaho Falls, Idaho 83415

http://www.inl.gov

Prepared for the

U.S. Department of Energy

Under DOE Idaho Operations Office

Contract DE-AC07-05ID14517 
Evaluation of Microreactor Inhalation Dose Consequences

\begin{tabular}{|c|c|}
\hline 1. Effective Date & $04 / 29 / 20$ \\
\hline $\begin{array}{l}\text { 2. Does this ECAR involve a } \\
\text { Safety SSC? }\end{array}$ & No \\
\hline $\begin{array}{l}\text { 3. Safety SSC Determination } \\
\text { Document ID }\end{array}$ & $\mathrm{N} / \mathrm{A}$ \\
\hline 4. SSC ID & $\mathrm{N} / \mathrm{A}$ \\
\hline 5. Project No. & --- \\
\hline 6. Engineering Job (EJ) No. & $\mathrm{N} / \mathrm{A}$ \\
\hline 7. Building & $\mathrm{N} / \mathrm{A}$ \\
\hline 8. Site Area & INL \\
\hline
\end{tabular}

Professional Engineer's Stamp

9. Objective / Purpose

The new generation of microreactors are intended to provide useful, very reliable and safe energy for a variety of applications, such as supplying power to remote locations. Microreactors range from less than $1 \mathrm{MW}_{\text {th }}$ to more than $20 \mathrm{MW}_{\text {th }}$. A range of technologies is being considered, including variations in neutron energy spectrum (fast or thermal), variations in primary and secondary coolant choices (e.g., metal-cooled, gas-cooled, and unique power cycle reactors). The reactors tend to use new fuel forms and types with unique benefits, such as metal or TRISO fuel for higher fuel density and safety, respectively. The notional image of a microreactor is a reactor that fits in a seavan or intermodal shipping container. This would allow conventional shipping options, including aircraft, and match other mobile power sources.

A development of a capability to test these reactors is needed, whether in a facility or in an open area. INL is in the process of determining acceptable test areas for these various reactors and an understanding of potential bounding consequences is important in informing siting and required infrastructure capability decisions. This ECAR considers the bounding release fractions of these types of reactors at $20 \mathrm{MWth}$ and documents the dose consequences to the public and collocated worker. This is a scoping analysis for the generalized type of reactor, and the analysis will be refined based on the specific reactor design.

10. If revision, please state the reason and list sections and/or page being affected. N/A

\section{Conclusion / Recommendations}

The radionuclide distributions and bounding release fractions of various reactor fuel types are documented in this report. The inhalation dose consequences for those reactors operating at $20 \mathrm{MWth}$ for one year are shown in the document below. 


\section{CONTENTS}

PROJECT ROLES AND RESPONSIBILITIES

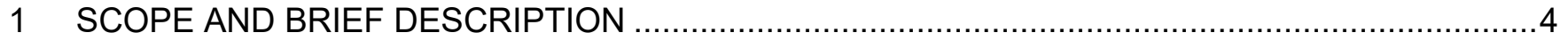

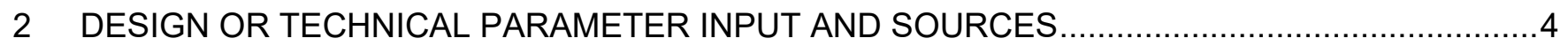

3 RESULTS OF LITERATURE SEARCHES AND OTHER BACKGROUND DATA ........................4

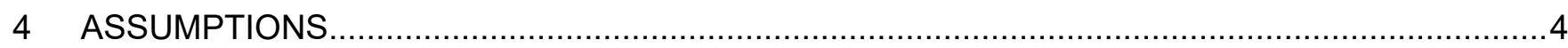

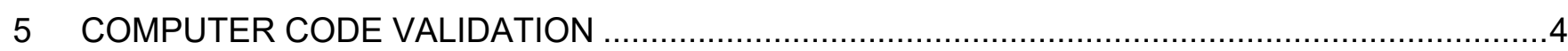

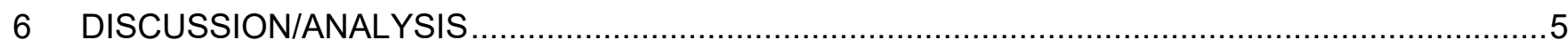

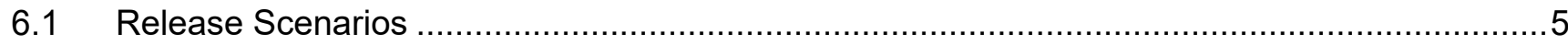

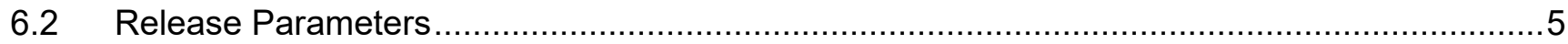

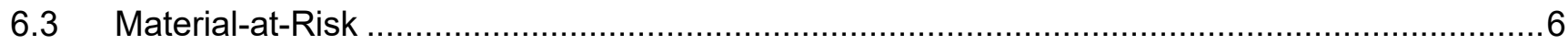

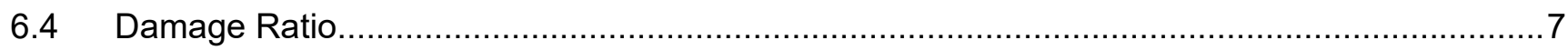

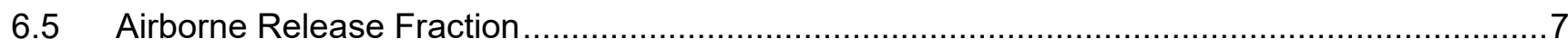

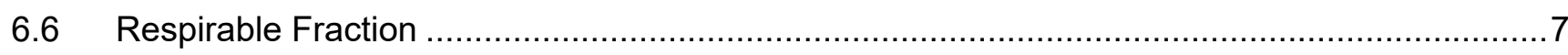

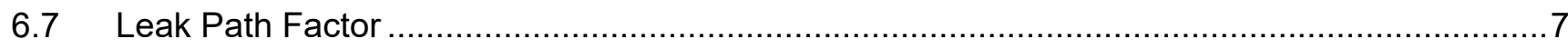

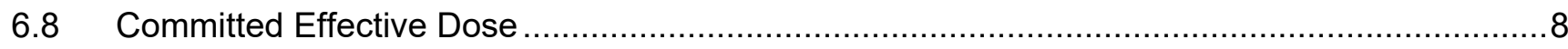

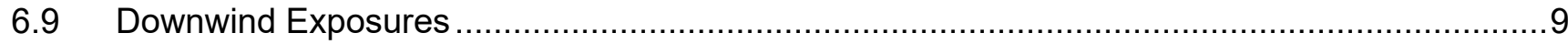

6.10 Bounding Inhalation Dose Consequences ..........................................................10

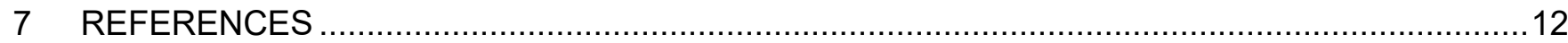

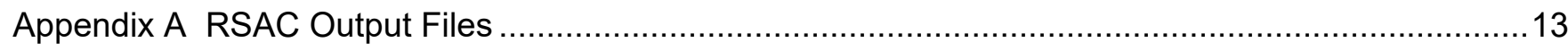

\section{TABLES}

Table 1. Actinide distribution for $20 \mathrm{MWth}$ reactor run at one year. ............................................

Table 2. Airborne release fractions and respirable fractions..................................................

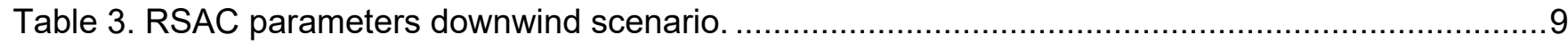

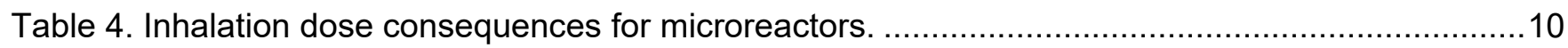


Evaluation of Microreactor Inhalation Dose Consequences

\section{PROJECT ROLES AND RESPONSIBILITIES}

\begin{tabular}{|l|c|c|c|}
\hline \multicolumn{1}{|c|}{ Project Role } & Name & Organization & Pages Covered (if applicable) \\
\hline Performer & Troy P. Reiss & H350 & See eCR 678011 \\
\hline Checker $^{\mathrm{a}}$ & Doug Gerstner & $\mathrm{H} 372$ & See eCR 678011 \\
\hline Independent Reviewer $^{\mathrm{b}}$ & $\mathrm{N} / \mathrm{A}$ & $\mathrm{N} / \mathrm{A}$ & $\mathrm{N} / \mathrm{A}$ \\
\hline CUI Reviewer $^{\mathrm{c}}$ & $\mathrm{N} / \mathrm{A}$ & $\mathrm{N} / \mathrm{A}$ & See eCR 678011 \\
\hline Manager $^{\mathrm{d}}$ & Jason P. Andrus & H350 & See eCR 678011 \\
\hline Requestor $^{\text {ef }}$ & Alison Conner & B662 & N/A \\
\hline Nuclear Safety & N/A & N/A & See eCR 678011 \\
\hline Document Owner & Jason P. Andrus & H350 & See eCR 678011 \\
\hline Reviewer $^{f}$ & Jess Gehin & C000 & \\
\hline
\end{tabular}

\section{Responsibilities:}

a. Confirmation of completeness, mathematical accuracy, and correctness of data and appropriateness of assumptions.

b. Concurrence of method or approach. See definition, LWP-10106.

c. Concurrence with the document's markings in accordance with LWP-11202.

d. Concurrence of procedure compliance. Concurrence with method/approach and conclusion.

e. Authorizes the commencement of work of the engineering deliverable. See Appendix A.

f. Concurrence with the document's assumptions and input information. See definition of Acceptance, LWP-10200.

NOTE: Delete or mark "N/A" for project roles not engaged. Include ALL personnel and their roles listed above in the eCR system. The list of the roles above is not all inclusive. If needed, the list can be extended or reduced. 


\section{SCOPE AND BRIEF DESCRIPTION}

The new generation of microreactors are intended to provide useful, very reliable, and safe energy for a variety of applications, such as supplying power to remote locations. Microreactors range from less than $1 \mathrm{MW}_{\text {th }}$ to more than $20 \mathrm{MW}_{\text {th }}$. A range of technologies is being considered including air-cooled, fast, thermal, metal-cooled, helium-cooled, and unique power cycle reactors. The reactors tend to use metal or tristructural isotropic (TRISO) fuel for higher fuel density and safety, respectively. The notional image of a microreactor is a reactor that fits in a seavan or intermodal shipping container. This would allow conventional shipping options, including aircraft, and match other mobile power sources.

A development of a capability to test these reactors is needed, whether in a facility or in an open area. INL is in the process of determining acceptable test areas for these various reactors and an understanding of potential bounding consequences is important in informing siting and required infrastructure capability decisions. This ECAR considers the bounding release fractions of these types of reactors at $20 \mathrm{MW}$ th and documents the dose consequences to the public and collocated worker. This is a scoping analysis for the generalized type of reactor, and the analysis will be refined based on the specific reactor design.

\section{DESIGN OR TECHNICAL PARAMETER INPUT AND SOURCES}

Technical parameter input and sources are identified in the text as appropriate.

\section{RESULTS OF LITERATURE SEARCHES AND OTHER BACKGROUND DATA}

The documents used to develop radionuclide inventories and bounding dose consequences are identified in the text as appropriate.

\section{ASSUMPTIONS}

Facility worker dose consequence is assumed to be equivalent to the collocated worker dose consequence calculations based on recognition of the remote operations of an operating reactor and evacuation from the facility.

All other assumptions are described in the text as appropriate.

\section{COMPUTER CODE VALIDATION}

A. Computer type:

Dell Precision 5810

Property Tag Number: 602037

B. Operating System and Version: Windows 10 Enterprise

C. Computer program name and revision: Microsoft Excel 365 ProPlus. The Excel spreadsheet software was used to document and calculate the inventory for this ECAR. The calculations are simple mathematical equations, which can be verified by hand calculations.

D. Computer program name and revision: Radiological Safety Analysis Computer Program (RSAC) 7.2. RSAC 7.2 program is a radiological safety analysis program that has been used extensively at 
INL for calculating the doses to facility worker, collocated workers, and off-site public due to radiological releases. It has been independently verified and validated for these types of calculations. Evidence of, or reference to, computer program validation: RSAC 7.2 configuration management is maintained in Enterprise Architecture under configuration number 223954. RSAC 7.2 was used to calculate final dose consequences for this ECAR. Case study verification for program installation on each computer platform was successfully completed by running each of the 20 example problems under the RSAC QC menu option.

E. Computer program name and revision: SCALE 6.2.1. The SCALE program was used to produce a scoping actinide distribution. The SCALE verification was run that provides sample problems whose results can be compared to a set of referenced results. The verification provides any differences from the reference results. If no differences or minimal differences are noted for a particular sample problem, SCALE has been properly installed for the tested functionality. No differences were noted after running the SCALE verification.

\section{DISCUSSION/ANALYSIS}

\subsection{Release Scenarios}

The release scenarios for microreactors analyzed in this document consist of fuel failure events coupled with a reactor boundary breach. Five release scenarios have been analyzed with reactor operations at 20 MWth for one year: 100\% fuel/fission product release (an extremely conservative and non-mechanistic evaluation) and fuel form-specific catastrophic bounding release events for sodium fast reactor (SFR) with metal fuel release, molten chloride salt fast reactor (MCFR) with liquid fuel release, high temperature gas reactor (HTGR) with TRISO fuel compacts release, and a pressurized water reactor (PWR) fuel release. Although TRISO fuel was analyzed for inclusion in this document, the complexities of an HTGR analysis are based on particle type, and source terms are based on a functional containment argument for the reactor. The intent of this ECAR is to provide bounding fuel release calculation and not consider other containment barriers. To ensure adequacy, bounding scoping calculations were performed for TRISO particles, and the releases from a TRISO fuel are bound by other fuel types analyzed in this document. Therefore, TRISO fuel is not a limiting case for this analysis and the subsequent decisions that it would inform related to siting and required support systems and will not be discussed further in this document.

\subsection{Release Parameters}

The accident-specific parameters used to evaluate the dose to downwind receptors requires that certain assumptions be made that modify the dispersion release fraction due to the physical aspects of the release. The five components of the following source term equation recommended by DOE-HDBK-3010-94, "Airborne Release Fractions/Rates and Respirable Fractions for Nonreactor Nuclear Facilities,"1 contain the basis for the material release parameters. To calculate downwind radiological doses for these scenarios, a source term (ST) was determined. The ST is the amount of radioactive material released during the postulated accident scenario. The STs are determined using the following equation:

$S T=M A R \times D R \times A R F \times R F \times L P F$

Where:

$S T=$ source term 


$\begin{array}{lll}M A R & = & \text { material-at-risk } \\ D R & = & \text { damage ratio } \\ A R F & = & \text { airborne release fraction } \\ R F & = & \text { respirable fraction } \\ L P F & = & \text { leak path factor }\end{array}$

\subsection{Material-at-Risk}

The material-at-risk (MAR) is the total inventory that could be impacted for a given accident scenario and is expressed in terms of total quantity at risk. The radiological inventories used for this accident analysis are based on the radionuclide distributions in Table 1 and the fission product inventory as calculated in RSAC. Table 1 provides a scoping actinide isotopic distribution based on a 3\% enriched low-enriched uranium (LEU) fuel that was generated in SCALE. The assumptions for SCALE is 1 metric ton of uranium at $20 \mathrm{MWth}$ for one year with a burnup of 7,300 MW days. The candidate fuel for most microreactors is high assay low enriched uranium (HALEU) that is slightly less than $20 \%$ enrichment to achieve higher power densities. Using 3\% enriched fuel is conservative for this analysis because there is more transuranic activation due to the higher quantity of U-238 in lower enriched fuel.

The fission products are calculated using RSAC-7.2, which establishes an inventory of fission products (and subsequent decay products) by simulating the operation of a steady-state thermal reactor. RSAC does not assume an initial uranium loading, and the fission products are determined by number of fissions to obtain the required burnup. A comparison of the fission product dose calculated in RSAC was compared to the activation and fission products calculated in SCALE. There was not a significant difference in the resulting dose consequence, and transuranic activation was not a major contributor in the results compared to the fission products (I, Cs, and Sr) for an immediate release.

This analysis covers thermal spectrum and fast spectrum reactors, and although a fast fission spectrum is different from a thermal spectrum, the differences between the spectrums are bound within the conservative assumptions of this scoping analysis. The fission product distribution is shown in the RSAC output files by dose significance. 
Table 1. Actinide distribution for $20 \mathrm{MWth}$ reactor run at one year.

\begin{tabular}{|c|c|}
\hline Isotope & Grams \\
\hline $\mathrm{U}-234$ & $8.99 \mathrm{E}+03$ \\
\hline $\mathrm{U}-235$ & $2.34 \mathrm{E}+04$ \\
\hline $\mathrm{U}-236$ & $6.15 \mathrm{E}+03$ \\
\hline $\mathrm{U}-237$ & $6.52 \mathrm{E}+00$ \\
\hline $\mathrm{U}-238$ & $9.51 \mathrm{E}+05$ \\
\hline $\mathrm{Np}-237$ & $2.04 \mathrm{E}+02$ \\
\hline $\mathrm{Np}-239$ & $3.83 \mathrm{E}+01$ \\
\hline $\mathrm{Pu}-238$ & $1.66 \mathrm{E}+01$ \\
\hline $\mathrm{Pu}-239$ & $2.63 \mathrm{E}+03$ \\
\hline $\mathrm{Pu}-240$ & $3.55 \mathrm{E}+02$ \\
\hline $\mathrm{Pu}-241$ & $1.08 \mathrm{E}+02$ \\
\hline $\mathrm{Pu}-242$ & $6.93 \mathrm{E}+00$ \\
\hline $\mathrm{Am}-241$ & $1.35 \mathrm{E}+00$ \\
\hline
\end{tabular}

\subsection{Damage Ratio}

The damage ratio (DR) represents the fraction of MAR that could be affected by the postulated accident and is a function of the accident initiator and the operational scenario being evaluated. DRs are determined based on engineering judgment, best available information, and prior analyses. The DR for all scenarios is evaluated at 1.0. It assumes that the events are significant enough such that $100 \%$ of the fuel material is sufficiently impacted from the event to be released.

\subsection{Airborne Release Fraction}

The ARF is the coefficient used to estimate the amount of material suspended in the air as an aerosol, thus available for transport. The ARF is related to the physical stresses of a specific accident and the physical characteristics of the material involved in the accident. Each reactor fuel type has different ARF values based on the bounding accident to which the reactor fuel is subjected. The ARF values are listed in Table 2.

\subsection{Respirable Fraction}

The RF is the fraction of airborne particles that can be transported through air and inhaled into the pulmonary region of the human respiratory system. The RF includes particles having a $10-\mu \mathrm{m}$ aerodynamic equivalent diameter or less. The RF values are listed in Table 2.

\subsection{Leak Path Factor}

The leak path factor (LPF) is the fraction of material in the aerosol transported through some confinement deposition or filtration mechanism. Typically, this factor accounts for the amount of the airborne MAR that escapes from a building or room. LPFs are assumed to be 1.0 to ensure an unmitigated analysis. 


\section{Evaluation of Microreactor Inhalation Dose Consequences}

Table 2. Airborne release fractions and respirable fractions.

\begin{tabular}{|c|c|c|}
\hline Reactor Release Type & $\mathrm{ARF} \times \mathrm{RF}$ & Material, Release Conditions, and Reference \\
\hline $100 \%$ fuel and fission product & 1.0 & $\begin{array}{l}\text { Total amount of material available to be released from } \\
\text { reactor fuel during a reactor run. }\end{array}$ \\
\hline $\begin{array}{l}\text { SFR eutectic release, } \\
\text { Noble gases }(\mathrm{Xe}, \mathrm{Kr}) \\
\text { Halogens }(\mathrm{I}, \mathrm{Br}) \\
\text { Alkali metals }(\mathrm{Cs}, \mathrm{Rb}) \\
\text { Tellurium group (Te, } \mathrm{Sb}, \mathrm{Se}) \\
\text { Barium, strontium }(\mathrm{Ba}, \mathrm{Sr}) \\
\text { Noble metals ( } \mathrm{Ru}, \mathrm{Rh}, \mathrm{Pd} \text {, } \\
\text { Mo, Tc, } \mathrm{Co}) \\
\text { Cerium group }(\mathrm{Ce}, \mathrm{Pu}, \mathrm{Np}) \\
\text { Lanthanides ( } \mathrm{La}, \mathrm{Zr}, \mathrm{Nd}, \mathrm{Nb} \text {, } \\
\text { Pm, Pr, Sm, Y, Cm, Am) } \\
\text { Eu } \\
\text { Remaining elements }\end{array}$ & $\begin{array}{l}0.67 \\
0.1 \\
0.42 \\
6.0 \mathrm{E}-3 \\
0.24 \\
6.0 \mathrm{E}-4 \\
6.0 \mathrm{E}-4 \\
6.0 \mathrm{E}-5 \\
0.42 \\
1.0 \mathrm{E}-03 \\
\end{array}$ & $\begin{array}{l}\text { The eutectic release fractions are derived from the eutectic } \\
\text { fuel pin failure events in ANL-ART- }-49^{2} \text { with scoping } \\
\text { calculations, and the event is judged to be applicable for an } \\
\text { SFR microreactor The fractions are the migration fractions } \\
\text { interpolated to } 6 \% \text { burnup from the input deck shown in the } \\
\text { ECAR. The resulting fractions may be conservative for a } \\
\text { release from a microreactor because some radionuclides } \\
\text { will be held up in the reactor vessel, and it assumes that that } \\
\text { the estimated releases are entirely airborne and respirable. }\end{array}$ \\
\hline $\begin{array}{l}\text { MSFR } \\
\text { Kr, Xe, I, Br, Cs, Rb } \\
\text { Remaining elements }\end{array}$ & $\begin{array}{l}1.0 \\
1 \mathrm{E}-04\end{array}$ & $\begin{array}{l}\text { The release from the molten salt reactor is assumed to be a } \\
\text { pressurized spray release, and all volatile fission products } \\
\text { are available for release. All other nuclides receive an } \\
\text { ARF } \times \mathrm{RF}=1 \mathrm{E}-04 \text { from DOE-HDBK-3010 Section } 3.2 .2 .3 .1 \\
\text { and supported by AU-30-RPT- } 02 .^{3} \text { The release fractions } \\
\text { assume no fission products have been removed from the salt } \\
\text { during reactor run and no chemical interaction of fission } \\
\text { products with salt. }\end{array}$ \\
\hline PWR LOCA & & This is a pressurized water reactor (PWR) loss-of-coolant \\
\hline Noble gases (Xe, Kr) & 1.0 & accident \\
\hline Halogens (I, Br) & 0.4 & \\
\hline Alkali metals (Cs, Rb) & 0.3 & \\
\hline Tellurium group $(\mathrm{Te}, \mathrm{Sb}, \mathrm{Se})$ & $5.0 \mathrm{E}-02$ & \\
\hline Barium, strontium $(\mathrm{Ba}, \mathrm{Sr})$ & $2.0 \mathrm{E}-02$ & \\
\hline $\begin{array}{l}\text { Noble metals }(\mathrm{Ru}, \mathrm{Rh}, \mathrm{Pd} \text {, } \\
\mathrm{Mo}, \mathrm{Tc}, \mathrm{Co})\end{array}$ & $2.5 \mathrm{E}-03$ & \\
\hline Cerium group $(\mathrm{Ce}, \mathrm{Pu}, \mathrm{Np})$ & $5.0 \mathrm{E}-04$ & \\
\hline $\begin{array}{l}\text { Lanthanides (La, Zr, Nd, Eu, } \\
\mathrm{Nb}, \mathrm{Pm}, \mathrm{Pr}, \mathrm{Sm}, \mathrm{Y}, \mathrm{Cm}, \mathrm{Am})\end{array}$ & $2.0 \mathrm{E}-04$ & \\
\hline Remaining elements & $1.0 \mathrm{E}-04$ & \\
\hline
\end{tabular}

\subsection{Committed Effective Dose}

The committed effective dose (CED) for downwind receptors is estimated from: 


$\begin{array}{lll}\mathrm{CED} & = & \mathrm{ST} \times \chi / \mathrm{Q} \times \mathrm{BR} \times \mathrm{DCF} \times \mathrm{DDF} \\ C E D & = & \text { committed effective dose } \\ S T & = & \text { source term }(\mathrm{Ci}) \\ \chi / Q & = & \text { plume dispersion }\left(\mathrm{s} / \mathrm{m}^{3}\right) \\ B R & = & \text { breathing rate }\left(\mathrm{m} / \mathrm{s}^{3}\right) \\ D C F & = & \text { dose conversion factor }(\mathrm{rem} / \mathrm{ci}) \\ D D F & = & \text { fraction of radionuclide remaining in plume after dry deposition (no units) }\end{array}$

The plume dispersion $(\chi / \mathrm{Q})$ value is a function of the meteorological conditions involved in the accident and relative location of the release point and the receptor and is calculated in RSAC. $\chi / Q$ is considered to be constant for all radionuclides of respirable size in an event and is independent of particular radionuclide and source types. Breathing rate (BR) is the assumed breathing rate described in DOE O 440.1B, "Worker Protection Program for DOE," and is 3.33E-4 m³ $/ \mathrm{sec}$. ICRP-68, "Dose Coefficients for Intakes of Radionuclides by Workers," ${ }^{6}$ dose conversion factor (DCF) values were utilized in the CED calculation for facility and collocated workers, and ICRP-72 "Age-dependent Doses from Intakes of Radionuclides,"7 DCF values were utilized in the calculation of the CED for the public. In both cases, the RSAC default DCF, the DCF for the lung absorption type that would result in the highest dose, was selected. The dry deposition factor (DDF) accounts for the material that is removed from the plume via deposition on the ground and accounts only for plume depletion that is expected to occur, independent of weather conditions.

\subsection{Downwind Exposures}

RSAC-7 was used to quantify the doses of the postulated accidents. The program is used to calculate the doses from the release of radionuclides to the atmosphere. The meteorological capabilities of RSAC-7 include Gaussian plume diffusion for the Pasquill-Gifford, Hilsmeier-Gifford, and Markee diffusion models. The Markee model is used in this analysis for all scenarios because it was developed for INL sagebrush terrain for effluent releases from a few minutes to 15 minutes in duration. The RSAC input parameters are summarized in Table 3.

Table 3. RSAC parameters downwind scenario.

\begin{tabular}{ll}
\hline RSAC Input Parameters & Input Values \\
\hline Release elevation $(\mathrm{m})$ & 0 \\
Stability class & $\mathrm{F}$ \\
Wind speed (m/second) & 1.04 \\
Diffusion coefficient & Markee \\
Downwind receptor distance $(\mathrm{m})$ & $100,4,700$ \\
Breathing rate $\left(\mathrm{m}^{3} /\right.$ second) & $3.33 \mathrm{E}-04$ (default parameter) \\
\hline
\end{tabular}


The RSAC-7 program allows the user to specify meteorological conditions at the time of radiological release and to calculate diffusion, dispersion, and depletion factors. It also allows the user to perform a variety of dose calculations. An internal dose can be calculated for up to 15 human organs in addition to the inhalation pathway.

Doses from the ingestion, ground contamination, and air immersion exposure pathways are negligible and are not calculated for on-site workers or off-site public. Contribution to the doses from long-term ingestion of farm or garden products is very small because implementation of the emergency preparedness program provides adequate warning to the off-site public about harvesting and ingesting foods that could be contaminated as a result of a radiological release.

Univariate distributions of wind conditions were developed by combining wind speed class and stability class into one variable (i.e., wind condition) and deriving the probability distribution of this variable. ${ }^{8}$ Cumulative probability distributions were then developed based on rankings of the wind conditions, ranging from good to bad in terms of their effect on dispersion of airborne contaminants. Based on this work and 95\% meteorology, a stability class of $\mathrm{F}$ and a wind speed class of 1 (i.e., $1.04 \mathrm{~m} / \mathrm{second}$ ) were used for the RSAC-7 runs. ${ }^{9}$ A ground release was assumed for this scenario. Buoyant plume rise was not used. Receptor locations were at $100 \mathrm{~m}$ downwind from the release for the collocated worker, and a distance of 4,700 $\mathrm{m}$ was used for determining the off-site public dose, which is the nearest site boundary to the proposed microreactor location at the Materials and Fuels Complex (MFC) at INL.

\subsection{Bounding Inhalation Dose Consequences}

The bounding inhalation dose consequences are listed below in Table 4. The scenario for the release considers a reactor operating at $20 \mathrm{MW}$ th for one year continuously. An accident occurs where the reactor releases $100 \%$ of the radionuclide inventory instantly. All fission products and fuel activation products are in the fuel at the time of release; there is no plate out in the coolant system, no cleanup system, or chemical interactions with coolant. There is no decay time for the fuel.

Table 4. Inhalation dose consequences for microreactors.

\begin{tabular}{|cccc|}
\hline Release Type & Source & $\begin{array}{c}\text { Collocated } \\
\text { Worker, rem }\end{array}$ & Public, rem \\
\hline $100 \%$ & CED & $4.70 \mathrm{E}+05$ & $8.73 \mathrm{E}+03$ \\
Radionuclide & Cloud gamma & $1.59 \mathrm{E}+03$ & $2.37 \mathrm{E}+01$ \\
Release & Total & $4.72 \mathrm{E}+05$ & $8.75 \mathrm{E}+03$ \\
\hline Sodium Fast & CED & $1.53 \mathrm{E}+04$ & $2.51 \mathrm{E}+02$ \\
Reactor & Cloud gamma & $2.43 \mathrm{E}+02$ & $2.57 \mathrm{E}+00$ \\
Release & Total & $1.55 \mathrm{E}+04$ & $2.54 \mathrm{E}+02$ \\
\hline MCFR & CED & $3.35 \mathrm{E}+04$ & $3.28 \mathrm{E}+02$ \\
Release & Cloud gamma & $5.52 \mathrm{E}+02$ & $5.39 \mathrm{E}+00$ \\
& Total & $3.41 \mathrm{E}+04$ & $3.33 \mathrm{E}+02$ \\
\hline PWR & CED & $1.82 \mathrm{E}+04$ & $1.55 \mathrm{E}+02$ \\
LOCA & Cloud gamma & $2.97 \mathrm{E}+02$ & $3.52 \mathrm{E}+00$ \\
Release & Total & $1.85 \mathrm{E}+04$ & $1.59 \mathrm{E}+02$ \\
\hline
\end{tabular}


The dose consequences calculated are for a building with no containment or confinement function. This also represents testing on an open cement pad. There is no credit taken for reactor containment either. If the microreactor demonstration was to take place in a facility with a credited containment, a LPF could be applied to the dose consequences calculated in Table 4 based upon the credited performance. Also, credited reactor vessel retention could provide a reduction in release fractions. These reductions in release fractions would be shown in a reactor-specific dose consequence report. 


\section{REFERENCES}

1. DOE-HDBK-3010-94, “Airborne Release Fractions/Rates and Respirable Fractions for Nonreactor Nuclear Facilities,” Change 1, U.S. Department of Energy, March 2000.

2. ANL-ART-49, "Sodium Fast Reactor Mechanistic Source Term - Trial Calculation,” Vol. 0, October 2016.

3. AU-30-RPT-02, "Pressurized Spray Release Technical Report," U.S. Department of Energy, April 2019.

4. RG 1.183, “Alternative Radiological Source Terms for Evaluating Design Basis Accidents at Nuclear Power Reactors” U.S. Nuclear Regulatory Commission, July 2000.

5. DOE O 440.1B, "Worker Protection Program for DOE," Change 2, U.S. Department of Energy, March 2013.

6. ICRP-68, "Dose Coefficients for Intakes of Radionuclides by Workers," International Commission on Radiological Protection, 1994.

7. ICRP-72, “Age-Dependent Doses from Intakes of Radionuclides,” International Commission on Radiological Protection, 1996.

8. DOE-STD-3009-2014, "Preparation of Nonreactor Nuclear Facility Documented Safety Analysis," U.S. Department of Energy, November 2014.

9. Einerson, J. J., Air Dispersion Parameters for Use in Idaho National Engineering Laboratory Department of Energy Safety Analyses, EGG-WM-11243, Rev. 1, Idaho National Engineering and Environmental Laboratory, August 1994. 
Evaluation of Microreactor Inhalation Dose Consequences

\section{Appendix A}

\section{RSAC Output Files}

NOTE: The RSAC output file provided in this appendix is one example; a complete listing of output files is available in EDMS as supporting information for this ECAR as "ECAR-5065-RSAC_Rev_0". 


\section{Evaluation of Microreactor Inhalation Dose Consequences}

Radiological Safety Analysis Computer Program (RSAC 7.2.0)

Name: Windows User Company: Idaho National Laboratory

Serial: 134684

Computer: INL611704

Run Date: 04/23/2020

Run Time: 11:38:24

File: LEU $100 \%$.rsac

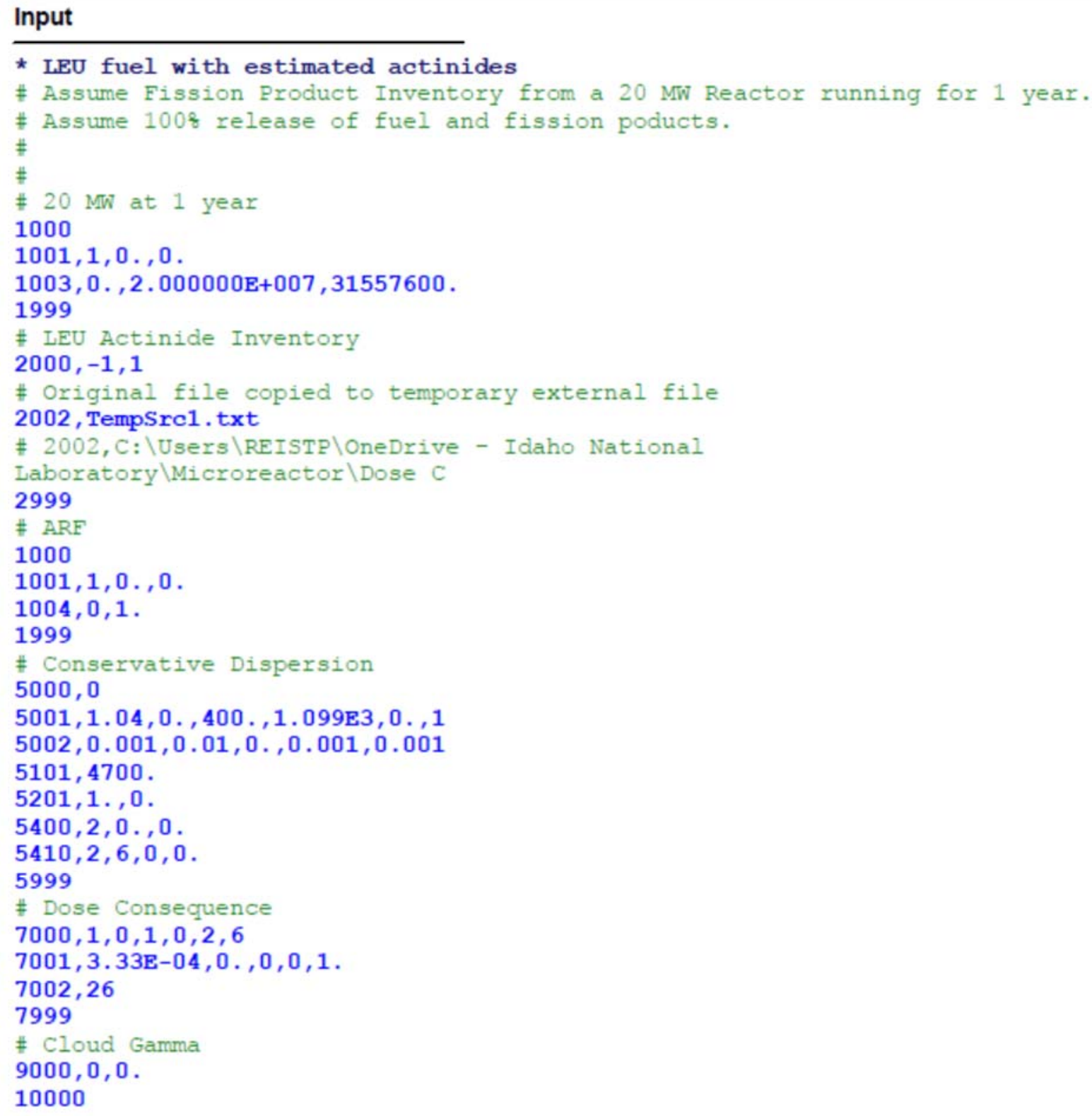


TEM-10200-1, Rev. 11 $11 / 20 / 2019$
ENGINEERING CALCULATIONS AND ANALYSIS

INL/EXT-20-58163/ECAR-5065,

Rev. 0

Page 15 of 17

Evaluation of Microreactor Inhalation Dose Consequences

Radiological Safety Analysis Computer Program (RSAC 7.2.0)

Name: Windows User Company: Idaho National Laboratory

Serial: 134684

Computer: INL611704

Run Date: 04/23/2020

Run Time: 11:38:24

File: LEU $100 \%$.rsac

\section{Fission Product Calculation}

RADIONUCLIDE INVENTORY HAS BEEN DECAYED FOR 0.000E+00 SECONDS

THE REACTOR HAS OPERATED AT $2.000 \mathrm{E}+07$ WATTS FOR $3.156 \mathrm{E}+07$ SECONDS BURNUP $=7.305 \mathrm{E}+03 \mathrm{MWD}$

TOTAL RADIONUCLIDE REMAINING $=3.499 \mathrm{E}+18 \mathrm{D} / \mathrm{S}$ OR $9.458 \mathrm{E}+07 \mathrm{CI}$

\section{Direct Radionuclide Input}

\begin{tabular}{|c|c|c|c|c|c|}
\hline RAD & $\begin{array}{l}\text { REVIOUS } \\
\text { DNUCLIDE }\end{array}$ & $\begin{array}{l}\text { INVENTORY I } \\
\text { INPUT READ }\end{array}$ & $\begin{array}{l}\text { CREA } \\
\text { FROM }\end{array}$ & $\begin{array}{l}\text { ED BY THE FOLLOWING VAL } \\
\text { EXTERNAL FILE USER FILE }\end{array}$ & TempSrc1.txt \\
\hline NUC & IDE & HALF I & FE & CURIE & \\
\hline 922340 & U234 & $2.455 E+05$ & $\mathrm{yr}$ & $8.990 \mathrm{E}+03 \quad 5.594 \mathrm{E}+01$ & \\
\hline 922350 & U235 & $7.038 E+08$ & $\mathrm{y} x$ & $2.340 \mathrm{E}+04 \quad 5.058 \mathrm{E}-02$ & \\
\hline 922360 & U236 & $2.342 E+07$ & $\mathrm{y} x$ & $6.150 \mathrm{E}+03 \quad 3.978 \mathrm{E}-01$ & \\
\hline 922370 & U237 & $6.750 \mathrm{E}+00$ & $\mathrm{~d}$ & $6.520 \mathrm{E}+00 \quad 5.322 \mathrm{E}+05$ & \\
\hline 922380 & U238 & $4.468 E+09$ & $\mathrm{y} x$ & $9.510 \mathrm{E}+05 \quad 3.197 \mathrm{E}-01$ & \\
\hline 932370 & Np237 & $2.144 \mathrm{E}+06$ & $\mathrm{yr}$ & $2.040 \mathrm{E}+02 \quad 1.435 \mathrm{E}-01$ & \\
\hline 932390 & Np239 & $2.356 \mathrm{E}+00$ & d & $3.830 \mathrm{E}+018.881 \mathrm{E}+06$ & \\
\hline 942380 & Pu238 & $8.770 \mathrm{E}+01$ & $\mathrm{yr}$ & $1.660 \mathrm{E}+012.843 \mathrm{E}+02$ & \\
\hline 942390 & Pu239 & $2.411 \mathrm{E}+04$ & $y x$ & $2.630 \mathrm{E}+03 \quad 1.632 \mathrm{E}+02$ & \\
\hline 942400 & Pu240 & $6.561 \mathrm{E}+03$ & $\mathrm{y} x$ & $3.550 \mathrm{E}+028.060 \mathrm{E}+01$ & \\
\hline 942410 & Pu241 & $1.429 \mathrm{E}+01$ & $\mathrm{y} r$ & $1.080 \mathrm{E}+02 \quad 1.121 \mathrm{E}+04$ & \\
\hline 942420 & Pu242 & $3.735 E+05$ & $\mathrm{yx}$ & $6.930 \mathrm{E}+002.741 \mathrm{E}-02$ & \\
\hline 52410 & $\operatorname{Am} 241$ & $4.326 \mathrm{E}+02$ & yr & $1.350 \mathrm{E}+004.629 \mathrm{E}+00$ & \\
\hline
\end{tabular}

\section{Fission Product Calculation}

FRACTION OF RADIONUCLIDE INVENTORY RELEASED $=1.000 \mathrm{E}+00$ TOTAL RADIONUCLIDE REMAINING $=3.848 \mathrm{E}+18 \mathrm{D} / \mathrm{S}$ OR $1.040 \mathrm{E}+08 \mathrm{CI}$

\section{Meteorological Data}

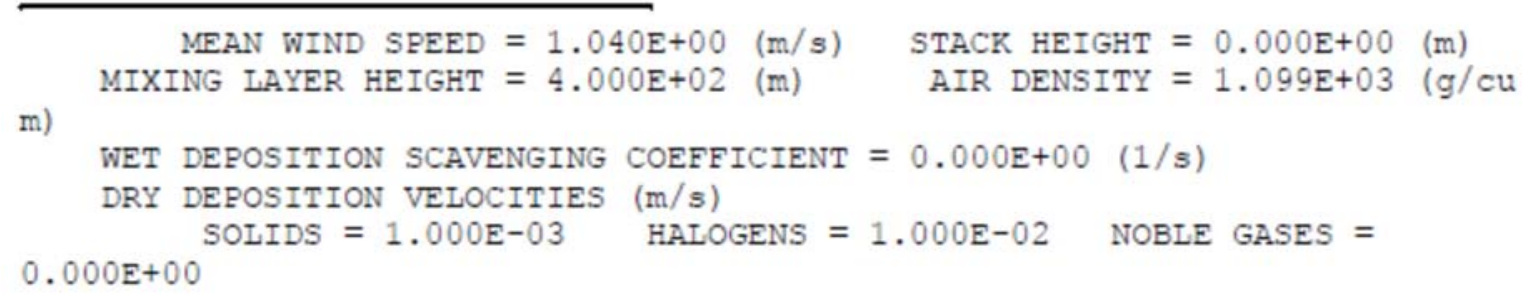


TEM-10200-1, Rev. 11 $11 / 20 / 2019$

\section{ENGINEERING CALCULATIONS AND ANALYSIS}

INL/EXT-20-58163/ECAR-5065,

Rev. 0

Page 16 of 17

Evaluation of Microreactor Inhalation Dose Consequences

Radiological Safety Analysis Computer Program (RSAC 7.2.0)

Name: Windows User Company: Idaho National Laboratory

Serial: 134684

Computer: INL611704 Run Date: 04/23/2020

Run Time: 11:38:24

File: LEU $100 \%$.rsac

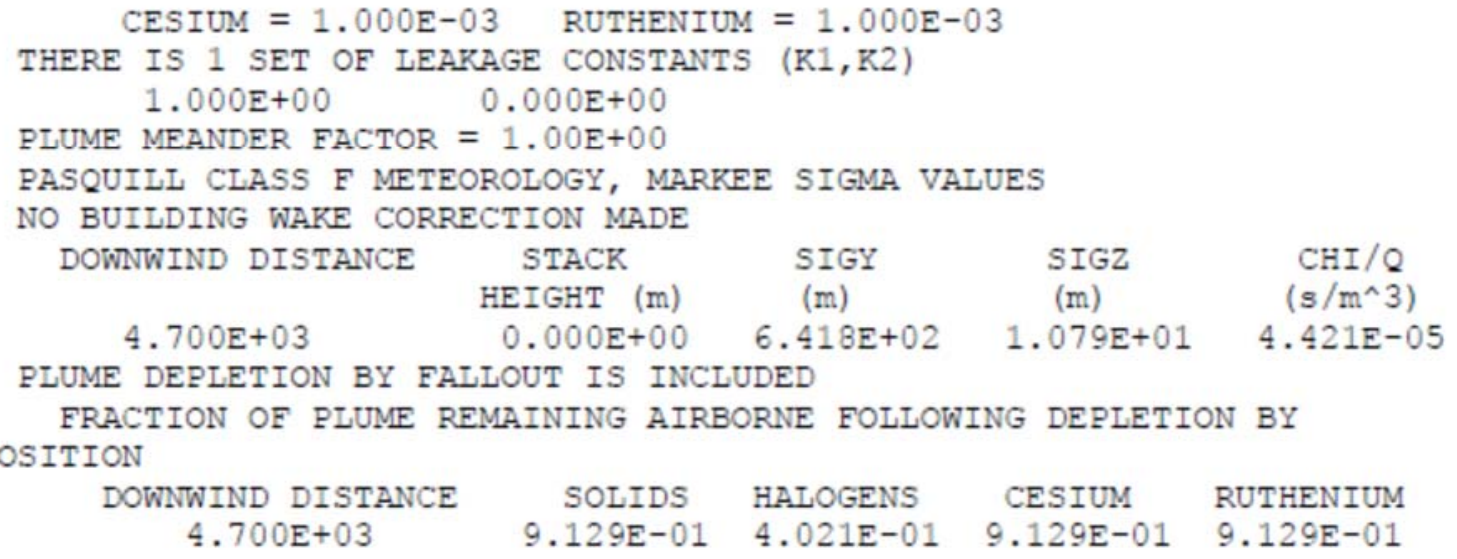

Inhalation Dose Calculation

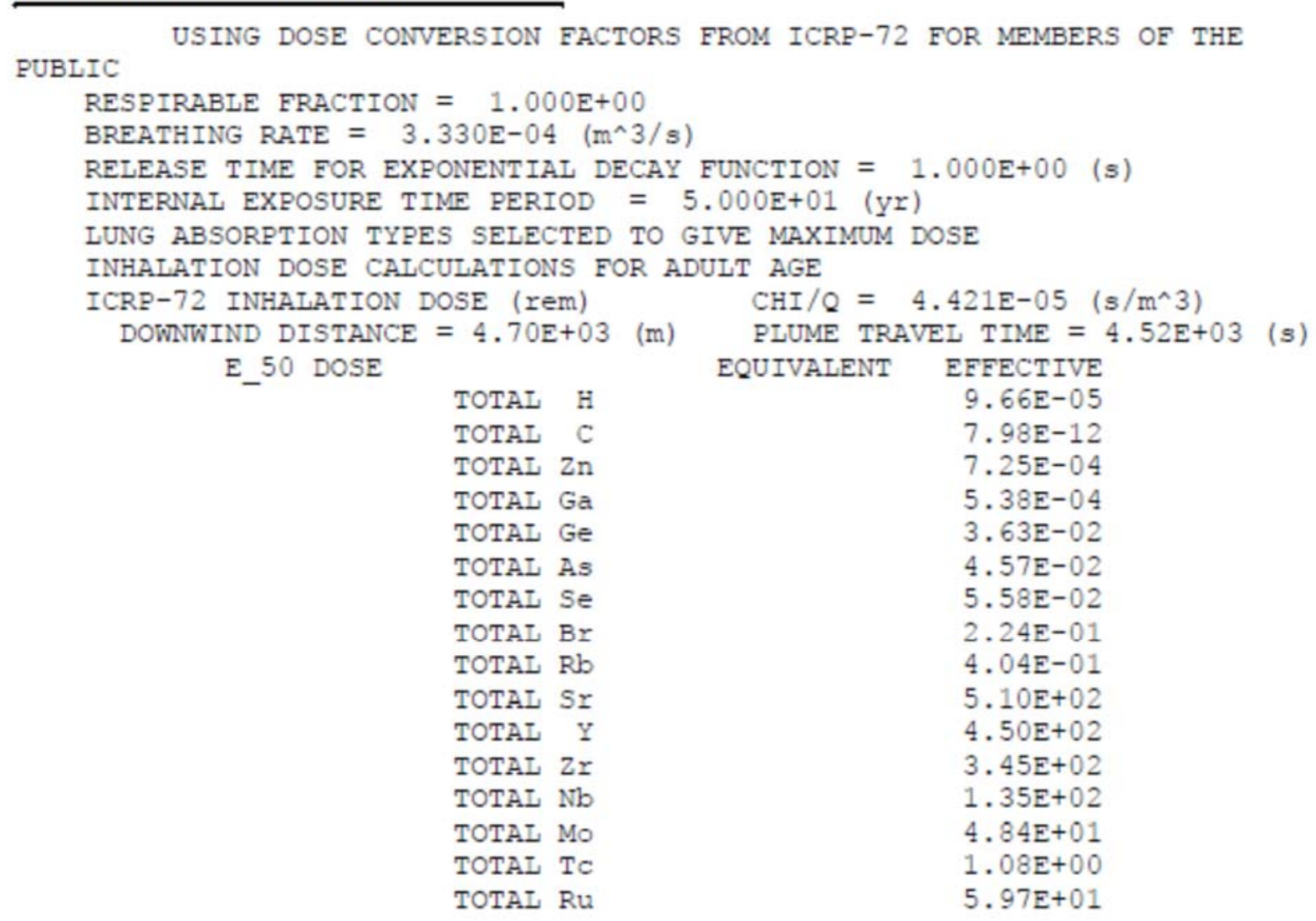


TEM-10200-1, Rev. 11 $11 / 20 / 2019$

\section{ENGINEERING CALCULATIONS AND ANALYSIS}

INL/EXT-20-58163/ECAR-5065,

Rev. 0

Page 17 of 17

\section{Evaluation of Microreactor Inhalation Dose Consequences}

Radiological Safety Analysis Computer Program (RSAC 7.2.0)

Name: Windows User Company: Idaho National Laboratory

Computer: INL611704 Run Date: 04/23/2020

File: LEU $100 \%$.rsac
Serial: 134684

Run Time: 11:38:24

$\begin{array}{cc}\text { TOTAL Rh } & 3.02 \mathrm{E}+00 \\ \text { TOTAL Pd } & 1.43 \mathrm{E}-01 \\ \text { TOTAL Ag } & 4.16 \mathrm{E}-01 \\ \text { TOTAL Cd } & 2.13 \mathrm{E}-01 \\ \text { TOTAL In } & 1.70 \mathrm{E}-02 \\ \text { TOTAL Sn } & 6.94 \mathrm{E}-01 \\ \text { TOTAL Sb } & 4.80 \mathrm{E}+00 \\ \text { TOTAL Te } & 1.91 \mathrm{E}+02 \\ \text { TOTAL I } & 2.67 \mathrm{E}+02 \\ \text { TOTAL Cs } & 6.21 \mathrm{E}+01 \\ \text { TOTAL Ba } & 2.98 \mathrm{E}+02 \\ \text { TOTAL Ia } & 6.52 \mathrm{E}+01 \\ \text { TOTAL Ce } & 1.60 \mathrm{E}+03 \\ \text { TOTAL } \mathrm{Pr} & 1.21 \mathrm{E}+02 \\ \text { TOTAL Nd } & 4.50 \mathrm{E}+01 \\ \text { TOTAL } \mathrm{Pm} & 5.42 \mathrm{E}+01 \\ \text { TOTAL Sm } & 3.33 \mathrm{E}+00 \\ \text { TOTAL Eu } & 1.97 \mathrm{E}+00 \\ \text { TOTAL Gd } & 3.31 \mathrm{E}-03 \\ \text { TOTAL Pb } & 4.37 \mathrm{E}-17 \\ \text { TOTAL Bi } & 9.72 \mathrm{E}-19 \\ \text { TOTAL PO } & 5.17 \mathrm{E}-17 \\ \text { TOTAL Ra } & 5.07 \mathrm{E}-17 \\ \text { TOTAL Ac } & 2.57 \mathrm{E}-17 \\ \text { TOTAL Th } & 2.63 \mathrm{E}-07 \\ \text { TOTAL Pa } & 3.74 \mathrm{E}-08 \\ \text { TOTAL U } & 7.65 \mathrm{E}+01 \\ \text { TOTAL Np } & 7.43 \mathrm{E}+01 \\ \text { TOTAL Pu } & 4.29 \mathrm{E}+03 \\ \text { TOTAL } \mathrm{Am} & 2.21 \mathrm{E}+01 \\ \text { E_50 DOSE } & 8.73 \mathrm{E}+03\end{array}$

\section{Gamma Dose Calculation}

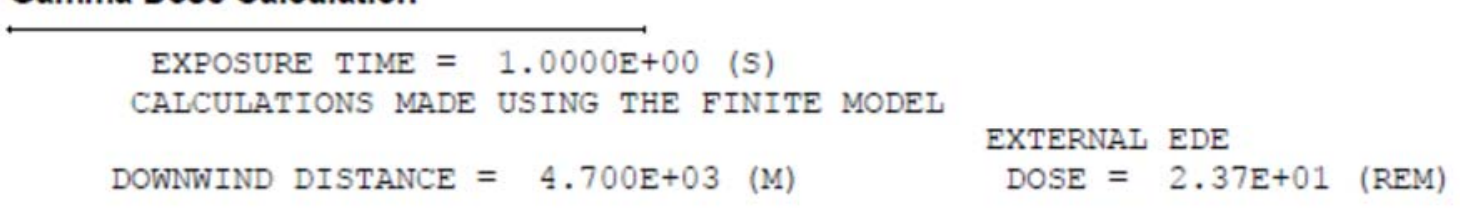

\section{Execution Time}

$$
6.00 \mathrm{E}-02 \text { SECONDS }
$$

